\title{
Procoagulant Activity of Human Mononuclear Leukocytes: Dissociation of the Effect of Mitogens on Procoagulant Activity and Mitogen-Stimulated Lymphocyte Proliferation
}

\author{
KENNETH C. RICH, ${ }^{(26)}$ R. A. ROBINS, AND E. RICHARD STIEHM \\ Departments of Pediatrics, Microbiology, and Immunology. University of California, School of Medicine, Los Angeles, \\ California 90024, and Department of Pediatrics, Northwestern University Medical School, Chicago, Illinois, USA
}

\begin{abstract}
Summary
The role of mononuclear cells in generating procoagulant activity was examined by incubating Ficoll-Hypaque-separated mononuclear leukocytes with or without mitogens (phytohemagglutinin, pokeweed mitogen, and concanavalin $A$ ). The procoagulant activity was assayed by a modification of a one-stage plasma recalcification time. Significant procoagulant activity developed after $24 \mathrm{hr}$ incubation and was dose dependent; mitogens alone had no effect on the clotting time. The increase in activity was paralleled by the increase in tritiated thymidine incorporation into replicating DNA. However, mitomycin $\mathbf{C}$ had little inhibitory effect on the development of procoagulant activity, whereas thymidine incorporation was inhibited. The major procoagulant activity was associated with intact cells and not the conditioned supernatant. The removal of adherent mononuclear cells (mostly monocytes) by polystyrene bead columns abolished the procoagulant activity, whereas purification of mononuclear leukocyte populations for monocytes markedly increased the activity as compared to purified lymphocytes. The procoagulant activity was shown to act by the extrinsic limb of the coagulation sequence because substitution factor VII-deficlent plasma for normal plasma resulted in marked depression of procoagulant activity, whereas factor VIII-deficient plasma resulted in a clotting time only minimally longer than normal plasma. Thus, although procoagulant activity in cultures of mononuclear cells is stimulated by the mitogen reagent, these studies suggest that the activity may not be the result of the mitogenic effect on lymphocytes per se. Whether it is a direct effect of the mitogen on the adherent cell or is an effect of a contaminant of the mitogen reagent, such as endotoxin, remains to be determined.
\end{abstract}

\section{Speculation}

Fibrin formation is an important component of inflammatory responses. This study shows that mononuclear leukocytes can be activated to stimulate the formation of fibrin. This suggests that mononuclear leukocytes may play a key role in the deposition of fibrin in inflammatory responses.

Fibrin deposition is an integral event in the inflammation of immune reactions. Wood and Bick (22) first suggested a role of fibrin deposition in cell-mediated immune reactions by demonstrating that anticoagulation suppressed the occular reaction to tuberculin in sensitized rabbits. Cohen et al. (2) later showed that delayed hypersensitivity skin test reactions in previously sensitized guinea pigs were partially inhibited by anticoagulation with heparin; the ability to immunize other animals by cell transfer was unaffected. In humans, biopsies of delayed hypersensitivity skin test sites have demonstrated a characteristic intervascular pattern of fibrin deposition in the reticular dermis which is not seen in biopsies of nonreactive skin tests (3).
The mechanism for stimulating the fibrin deposition is not clear. However, previous work has demonstrated that many types of tissues, including leukocytes, exhibit procoagulant activity (4, $7,8,11,18,23)$. The procoagulant activity is accentuated by prior incubation of intact cells with endotoxin $(4,8,18)$. Rickles $e t$ al. (15), found that phytohemagglutinin stimulation of mononuclear cell cultures resulted in a significant increase in procoagulant activity within $24 \mathrm{hr}$. Inasmuch as phytohemagglutinin is a potent T-lymphocyte mitogen, this observation can be interpreted as evidence that stimulated $\mathrm{T}$-lymphocytes can mediate the deposition of fibrin in delayed hypersensitivity reactions. Therefore, in this study, we examined the development of procoagulant activity in mitogen-stimulated mononuclear leukocyte cultures. We present evidence to show that the resulting coagulant activity may not be due to the mitogenic effect of the lectins on lymphocytes per se but rather the result of activation of a population of adherent mononuclear cells by mitogen or a contaminating component of the reagent.

\section{MATERIALS AND METHODS}

\section{CELL PREPARATION AND CULTURE}

Blood was drawn from normal adult donors and defibrinated by gently swirling the blood with glass beads $(2$ to $3 \mathrm{~mm}$ in diameter) in siliconized glass flasks or polycarbonate tubes (Falcon Plastics, Oxnard, CA). The blood was diluted in buffer or in medium consisting of Roswell Park Memorial Institute medium 1640 (Grand Island Biological Co., Grand Island, NY) with 20\% heat-inactivated $\left(56^{\circ} \mathrm{C}\right.$ for $30 \mathrm{~min}$ ) fetal calf serum (Microbiological Associates, Bethesda, MD) and antibiotics (penicillin and streptomycin, 5000 units and $5000 \mu \mathrm{g}$, respectively, per $100 \mathrm{ml}$, or gentamycin, $1 \mathrm{mg} / 100 \mathrm{ml}$ ). The diluted blood was applied to a Ficoll-Hypaque gradient (density, $1.077 \mathrm{~g} / \mathrm{ml}$ ) and centrifuged at room temperature at $350 \times \mathrm{g}$ for $30 \mathrm{~min}$. After two washes, the cells were resuspended in medium, and the concentration of mononuclear cells was adjusted to $1 \times 10^{6} / \mathrm{ml}$. The cultures were incubated in polycarbonate tubes at $37^{\circ} \mathrm{C}$ in a moist $5 \% \mathrm{CO}_{2}$ atmosphere.

Adherent mononuclear cells were removed by incubating mononuclear cells from the Ficoll-Hypaque gradient for $30 \mathrm{~min}$ at $37^{\circ} \mathrm{C}$ in columns containing divinyl benzene/polystyrene beads as previously described (21). The nonadherent cells were eluted with medium.

Purified populations of monocytes were prepared by allowing the Ficoll-Hypaque prepared cells to adhere to tissue culture flasks for $30 \mathrm{~min}$ at $37^{\circ} \mathrm{C}$. The nonadherent cells were removed by washing five times with normal saline. The adherent monocytes were detached from the surface for counting by lidocaine treatment essentially as described by Rinehart et al. (17), except that for these studies $0.5 \mathrm{mM}$ lidocaine was used. The adherent and nonadherent cells were resuspended in culture media with $10 \%$ 
heat-inactivated autologous serum and incubated for $18 \mathrm{hr}$ before assay for procoagulant activity.

For certain experiments, the cell fraction and the supernatant were isolated and assayed separately. The cultures were centrifuged at $450 \times g$ for $10 \mathrm{~min}$, the supernatant was removed, and the cells were resuspended in an equal volume of fresh culture medium and assayed for procoagulant activity. The supernatant was assayed after recentrifugation $(1000 \times g$ for $10 \mathrm{~min})$ to ensure complete removal of cells. No cells were observed on microscopic examination of the supernatant.

Lymphocyte subpopulations were enumerated by sheep erythrocyte $(E)$ rosettes for $T$-lymphocytes and by trypsinized antibodycoated sheep erythrocytes (EA) rosettes for Fc receptor-bearing B-lymphocytes (24). The E rosette assay was performed by suspending sheep erythrocytes (SRBC) with an equal volume of cell suspension and incubating for $5 \mathrm{~min}$ at $37^{\circ} \mathrm{C}$. The cells were centrifuged for $5 \mathrm{~min}$ at $60 \times \mathrm{g}$ and left on ice for one hr before gently resuspending and counting. EA rosette-forming lymphocytes were assayed by mixing the lymphocyte suspension with trypsinized SRBC coated with a subagglutinating dilution of rabbit anti-SRBC serum. The cells were centrifuged at $60 \times g$ for $5 \mathrm{~min}$, resuspended, and counted. Cell surface immunoglobulin was assayed by fluorescence using a direct method with fluorescein-conjugated polyvalent goat antihuman immunoglobulin (Meloy, Springfield, VA).

\section{PROCOAGULANT ACTIVITY ASSAY}

The procoagulant activity was assayed by a modification of the standard one stage plasma recalcification time. One-tenth $\mathrm{ml}$ each of normal plasma (Verify Normal Citrate; General Diagnostics, Morris Plains, $\mathrm{NJ})$, calcium chloride $(0.025 \mathrm{M})$ and test material suspended in culture medium were preheated for $3 \mathrm{~min}$ at $37^{\circ} \mathrm{C}$, and the clotting time determined on a Fibrometer (BBL, Division Becton-Dickinson and Co., Cockeysville, MD). In experiments using purified monocytes, the clotting time was determined on a Coag-A-Mate Dual Channel Clot Detection Unit (General Diagnostics). Clotting times determined by both techniques gave similar results.

The mean clotting time of normal plasma in the presence of complete culture medium was $96 \mathrm{sec}$. The clotting time was found to be affected by lot-to-lot differences in reagents, by the duration of the incubation of the complete medium, and possibly by the presence of residual clotting factors in the fetal calf serum. A representative lot of complete culture medium was found to have $6 \%$ of normal factor $\mathrm{X}$ activity and $<1 \%$ factor $\mathrm{V}$ activity. The activated partial thromboplastin time was $>200$ sec. To take into account the variation in the baseline clotting time, a coagulation index was used to express the data. The coagulation index is the ratio of the clotting time of test material in culture medium to the clotting time of culture medium alone. An index of less than one indicates procoagulant activity, and the smaller the index, the greater the procoagulant activity. The replicate values generally agreed within $\pm 5 \%$.

\section{TRITIATED THYMIDINE INCORPORATION}

The tritiated thymidine incorporation was assayed by incubating $1 \times 10^{5}$ mononuclear cells in $0.2 \mathrm{ml}$ of complete medium in individual wells of a Microtiter plate for 5 days. Each well was then pulsed with $0.4 \mu \mathrm{Ci}$ of tritiated thymidine (New England Nuclear, Boston, MA) for 6 to $8 \mathrm{hr}$. The cells were then harvested by a Multiple Automated Sample Harvestor (Microbiological Associates), and the filters were counted in a liquid scintillation counter. Each determination was done in triplicate or quadruplicate.

Inhibition of DNA synthesis was studied by incubating the cultures with Mitomycin-C (ICN, Cleveland, $\mathrm{OH}$ ). Preliminary studies showed that a dose of mitomycin of $10 \mu \mathrm{g} / \mathrm{ml}$ resulted in complete inhibition of tritiated thymidine incorporation, although at $1 \mu \mathrm{g} / \mathrm{ml}$, the thymidine incorporation was twice background, whereas at $0.1 \mu \mathrm{g} / \mathrm{ml}$ it ranged from nine to 25 times background.

\section{OTHER REAGENTS}

Other reagents used were phytohemagglutinin (PHA) (Difco Laboratories, Detroit, MI), concanavalin A (Con A) (Sigma Chemical Co., St. Louis, MO), and pokeweed mitogen (PWM) (Grand Island Biological Co.).

\section{RESULTS}

\section{EFFECT OF PHA ON THE DEVELOPMENT OF PROCOAGULANT ACTIVITY}

The procoagulant activity of mononuclear cell populations increased when incubated with PHA (Fig. 1). Mononuclear cells from 16 normal adult donors were incubated with or without 10 $\mu l$ PHA per $\mathrm{ml}$ for varying periods of time. The effect of the cultured cells on the clotting time of normal plasma was compared to the effect of culture medium incubated for the same time without cells. For most experiments, this comparison was expressed as a ratio of the clotting time of the cell-containing cultures to the clotting time of the medium alone and was termed the coagulation index (Fig. 1, numbers in parentheses). Before incubation, minimal procoagulant activity was observed in the absence or presence of PHA. By $24 \mathrm{hr}$ incubation, the procoagulant activity of PHA-stimulated cultures increased significantly. An even greater difference between the unstimulated and stimulated cultures was observed by $48 \mathrm{hr}$. Additional incubation for $24 \mathrm{hr}$ did not further increase the procoagulant activity. The difference was statistically significant (by paired $t$ test) by $24 \mathrm{hr}$ at a level of $P$ $<0.005$. Disruption of the cells by three cycles of freezing and thawing before incubation prevented the time-dependent increase in procoagulant activity.

\section{EFFECT OF PHA DOSE ON PROCOAGULANT ACTIVITY AND DNA SYNTHESIS}

The procoagulant activity of incubated cultures increased with increasing concentration of PHA (Fig. 2). The cultures from seven normal donors developed procoagulant activity with a PHA dose as low as $0.1 \mu \mathrm{l} / 10^{5}$ cells $(1 \mu \mathrm{l} / \mathrm{ml})$ and reached a maximum at 1

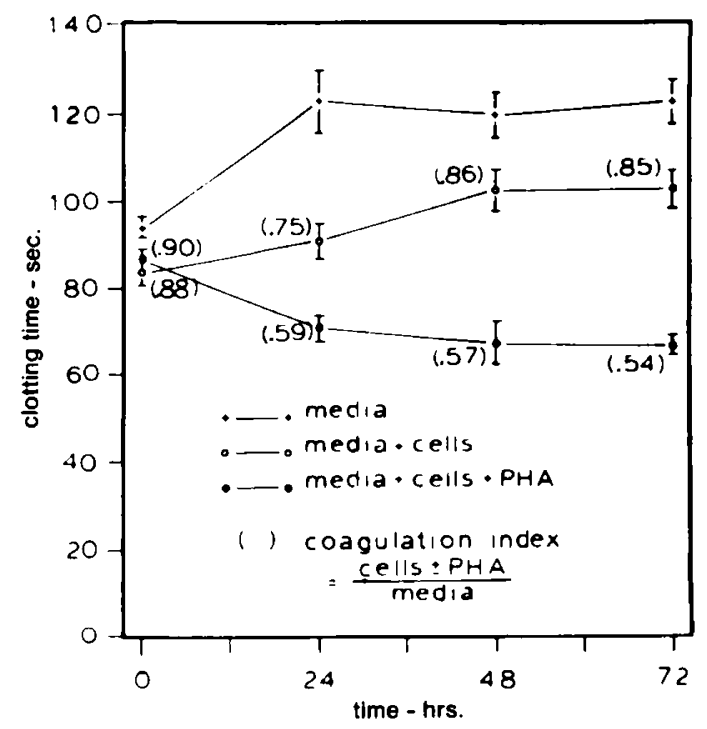

Fig. 1. Increase in procoagulant activity of mitogen-stimulated mononuclear cell culture with time. Cultures of mononuclear cells $\left(1 \times 10^{6} / \mathrm{ml}\right)$ in Roswell Park Memorial Institute medium 1640 with $20 \%$ fetal calf serum were incubated in the absence or presence of PHA, $10 \mu \mathrm{l} / \mathrm{ml}$. The clotting time of culture medium alone and of cell-containing cultures was measured by a one-stage plasma recalcification time. Most data in this study were expressed as a coagulation index or the ratio of the clotting time of cell-containing cultures to the clotting time of culture medium alone (numbers in parentheses). A significant difference in procoagulant activity was observed between the unstimulated control cultures and the PHA-stimulated cultures by 24 or more hr of incubation $(P<0.005)$. 
$\mu l$ PHA per $10^{5}$ cells $(10 \mu \mathrm{l} / \mathrm{ml})$. The difference between the unstimulated and stimulated cultures for each donor was significant by paired $t$ test at $P<0.01$. Tritiated thymidine incorporation was determined on parallel cultures as a measure of lymphocyte activation by PHA. The-thymidine incorporation increased with greater doses of PHA and reached a maximum coincident with maximum procoagulant activity at $1 \mu \mathrm{l} / 10^{5}$ cells.

\section{EFFECT OF OTHER MITOGENS}

PWM and Con A also stimulated procoagulant activity (Table 1). The procoagulant activity stimulated by incubation with PWM was similar in magnitude to that seen with PHA. Con A at low dose $(1 \mu \mathrm{m} / \mathrm{ml})$ failed to stimulate procoagulant activity, whereas at a higher dose $(10 \mu \mathrm{m} / \mathrm{ml})$, the cultures developed significant activity.

\section{LOCATION OF PROCOAGULANT ACTIVITY}

To determine whether the procoagulant factor is a secreted product, the supernatants of the incubated mononuclear cell cul-

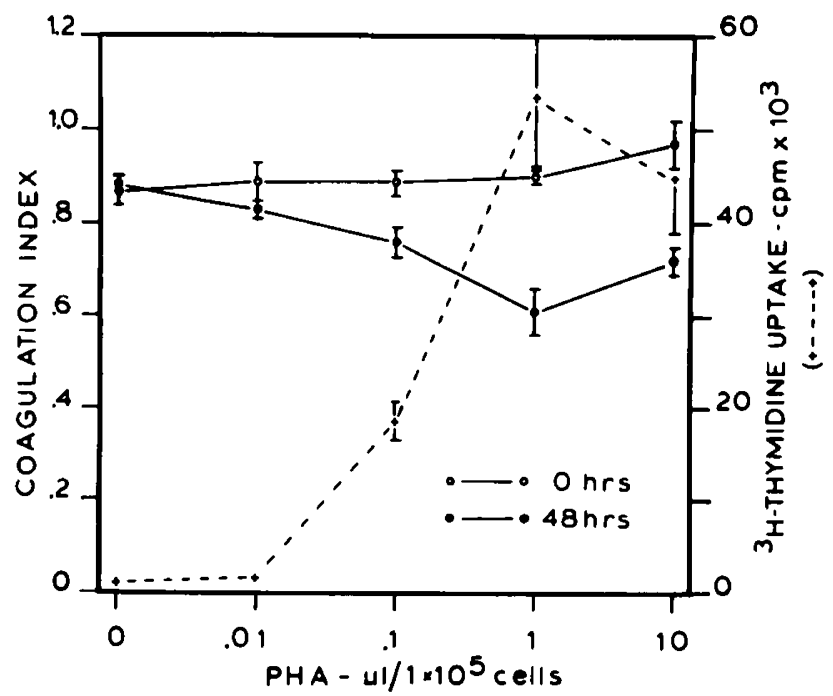

Fig. 2. Mitogen dose dependence of the generation of procoagulant activity. Procoagulant activity of mononuclear cells, expressed as a coagulation index, was determined before incubation $(O)$ and after $48 \mathrm{hr}$ incubation $(\theta)$. The difference in procoagulant activity was significant at a dose of $0.1 \mu \mathrm{PHA}$ per $10^{5}$ cells and greater. The tritiated thymidine incorporation $(+)$ was measured after 5 days incubation, was expressed as cpm $\left(\times 10^{3}\right)$ per culture $\left(2 \times 10^{5}\right.$ mononuclear cells), and was significantly greater than the control at doses of $0.1 \mu \mathrm{l}$ PHA per $10^{5}$ cells or greater.

Table 1. Procoagulant activity of mononuclear leukocyte cell cultures stimulated by PHA, PWM, and Con $A^{1}$

\begin{tabular}{lccc}
\hline & & \multicolumn{2}{c}{ Coagulation index } \\
\cline { 3 - 4 } \multicolumn{1}{r}{ Mitogen } & No. & $0 \mathrm{hr}$ & $48 \mathrm{hr}$ \\
\hline None & 13 & $0.88 \pm 0.02^{2}$ & $0.85 \pm 0.02$ \\
PHA & & & \\
$\quad 1 \mu \mathrm{l} / \mathrm{ml}$ & 13 & $0.89 \pm 0.02$ & $0.64 \pm 0.04^{3}$ \\
$10 \mu \mathrm{l} / \mathrm{ml}$ & 5 & $0.94 \pm 0.05$ & $0.72 \pm 0.03^{3}$ \\
$\mathrm{PWM}$ & & & \\
$\quad 1 \mu \mathrm{m} / \mathrm{ml}$ & 6 & $0.90 \pm 0.02$ & $0.75 \pm 0.04^{3}$ \\
$\quad 10 \mu \mathrm{m} / \mathrm{ml}$ & 6 & $0.87 \pm 0.03$ & $0.69 \pm 0.03^{3}$ \\
Con A & & & \\
$\quad 1 \mu \mathrm{m} / \mathrm{ml}$ & 6 & $0.87 \pm 0.02$ & $0.87 \pm 0.03$ \\
$10 \mu \mathrm{m} / \mathrm{ml}$ & 6 & $0.89 \pm 0.03$ & $0.58 \pm 0.07^{3}$ \\
\hline
\end{tabular}

${ }^{1}$ Incubation conditions were the same as Figure 1. Mitogens without cells have no effect on clotting time.

${ }^{2}$ Mean \pm S.E.

${ }^{3}$ The procoagulant activity is significantly greater than control unstimulated cultures $(P<0.02$ or less). tures were examined for procoagulant activity. As seen in Figure 3 , the procoagulant activity of the cell pellet resuspended in unconditioned medium was similar to the whole incubation mixture in both the unstimulated and stimulated cultures. The incubated conditioned supernatant of the PHA-stimulated cultures had significantly less procoagulant activity than the cell pellet $(P$ $<0.005$ ). A similar comparison of the unstimulated cultures was not statistically significant.

\section{EFFECT OF MITOMYCIN C ON DNA SYNTHESIS AND PROCOAGULANT ACTIVITY}

The role of DNA synthesis in the development of procoagulant activity was examined by adding mitomycin $\mathrm{C}$, an inhibitor of DNA synthesis, to the culture. PHA and mitomycin alone had no effect on procoagulant activity before incubation (Fig. $4 A$ ). After $48 \mathrm{hr}$ incubation, procoagulant activity was increased significantly in both the PHA cultures and in the PHA-mitomycin cultures. Addition of mitomycin to the unstimulated culture resulted in a slight increase in procoagulant activity at $48 \mathrm{hr}$, whereas it slightly reduced the activity of the mitogen-stimulated culture. Inhibition of DNA synthesis at the dose of mitomycin used in this study was confirmed by demonstrating that tritiated thymidine uptake was reduced to the level of the unstimulated cell culture (Fig. 4B). Thus, significant procoagulant activity develops in the absence of DNA synthesis.

\section{REDUCTION OF PROCOAGULANT ACTIVITY BY REMOVAL OF ADHERENT CELLS}

To determine the cell responsible for the development of procoagulant activity, the adherent cells were removed from the mononuclear cell populations by incubating them in columns of polystyrene beads. The adherent cell-depleted cell populations contained $1.5 \%$ monocytes compared to $11.5 \%$ monocytes in the

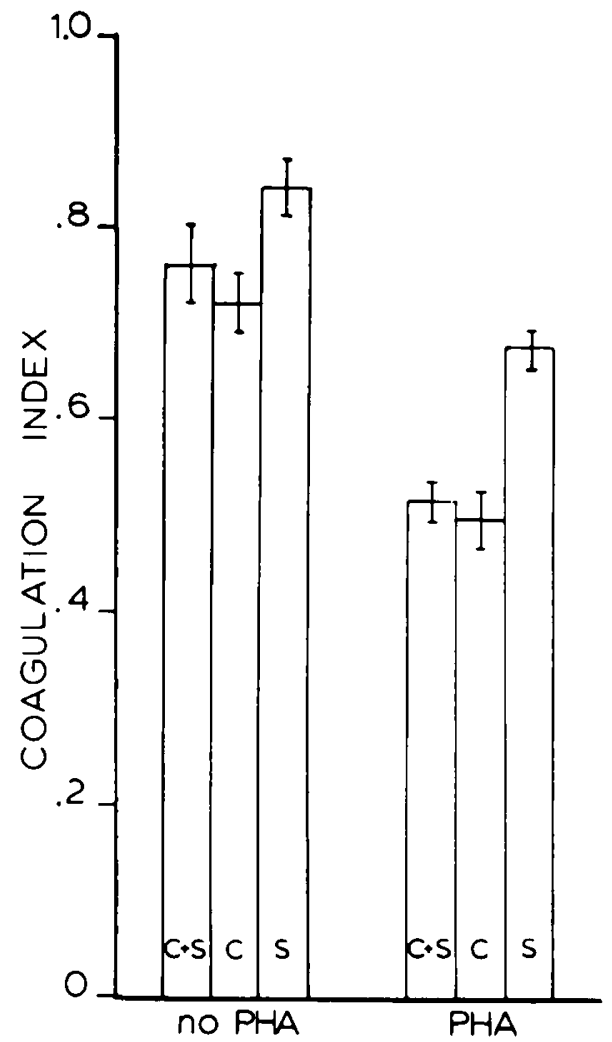

Fig. 3. Location of procoagulant activity of mononuclear cell culture. Greater activity is present in the cell pellet (C) of the PHA-stimulated culture than in the supernatant fluid from the same culture $(S) .(P<$ $0.005)$. The procoagulant activity of the whole incubation mixture $(C+S)$ is similar to the cell pellet $(n=6)$. 


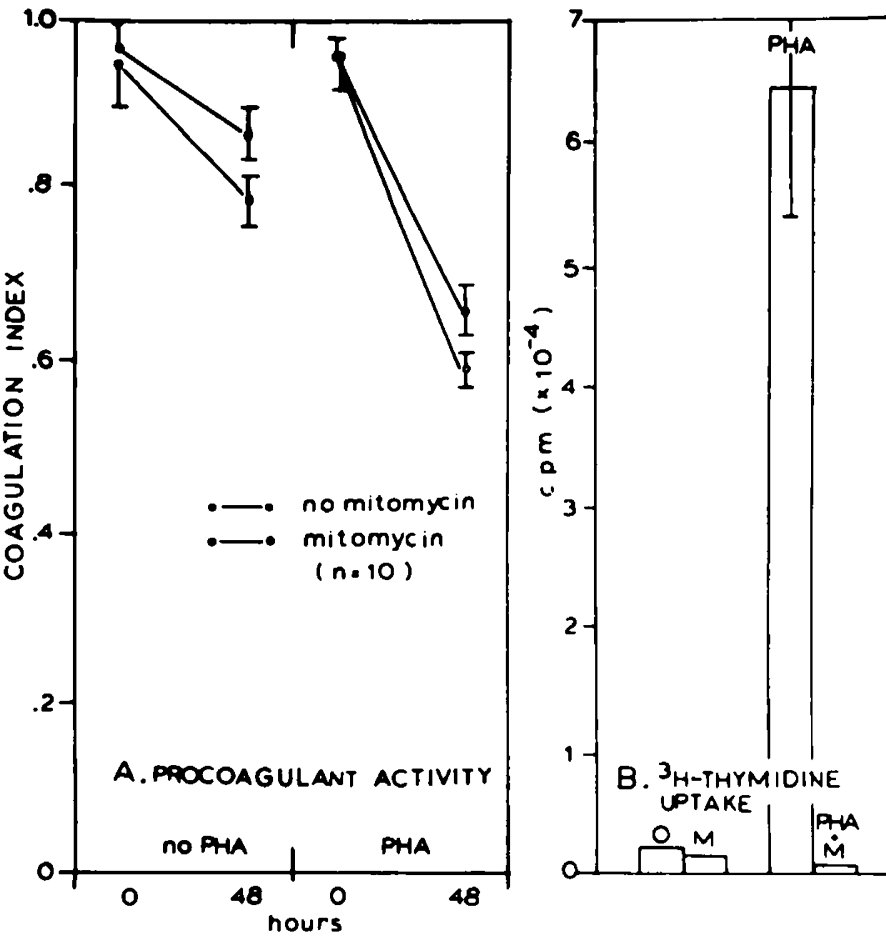

Fig. 4. Effect of mitomycin on mononuclear cell cultures. $A$, procoagulant activity. PHA-stimulated cultures with and without mitomycin treatment exhibited significantly greater procoagulant activity than unstimulated cultures $(P<0.025) ; B$, DNA synthesis. Mitomycin $(M)$ resulted in complete inhibition of tritiated thymidine incorporation of mitogenstimulated cultures.

nondepleted cell preparation (Table 2). The adherence step also reduced to some extent the proportion of EA-rosetting mononuclear cells $(25.0$ to $17.2 \%)$ and the proportion of cells that had receptors for fluorescinated polyvalent goat anti-human immunoglobulin (19.8 to $11.0 \%$ ). The procoagulant activity of the unstimulated adherent cell-depleted population was less than the nondepleted cell population. The procoagulant response to PHA of the adherent cell-depleted population was insignificant compared to the increase seen in nondepleted cell populations. Tritiated thymidine incorporation, on the other hand, was not significantly altered by depletion of adherent cells.

\section{ENHANCEMENT OF PROCOAGULANT ACTIVITY BY PURIFICATION OF MONOCYTES}

Monocytes were isolated by their adherent properties, and the activity generated during an 18 -hr incubation was compared to that of the nonadherent or lymphocyte fraction. The proportion of lymphocytes in the nonadherent population was $>95 \%$, whereas the proportion of monocytes in the adherent fraction as defined by peroxidase histochemical stain was $>90 \%$. Clotting times of the monocyte-enriched population in each case were significantly less than those of the lymphocyte-enriched population (Fig. 5). Thus, depletion of adherent cells reduced the procoagulant activity of mononuclear leukocyte populations, and enrichment for monocytes increased the activity, suggesting that monocytes play a role in the expression of leukocyte procoagulant activity.

\section{PROCOAGULANT ACTIVITY ACTS THROUGH THE EXTRINSIC LIMB} OF COAGULATION

If mononuclear leukocyte procoagulant activity acted through the extrinsic limb of coagulation, the recalcification time using plasma from patients congenitally deficient in factor VII should be prolonged, whereas if it acted through the intrinsic limb, the recalcification time with factor VIII-deficient plasma would be prolonged. Mononuclear leukocytes from four normal donors
Table 2. Effect of depletion of adherent cells on the procoagulant activity of mononuclear leukocyte cell cultures

\begin{tabular}{|c|c|c|}
\hline & $\begin{array}{l}\text { Mixed mononuclear } \\
\text { cell cultures' }\end{array}$ & $\begin{array}{l}\text { Adherent cell-de- } \\
\text { pleted mononuclea } \\
\text { cell cultures }{ }^{2}\end{array}$ \\
\hline \multicolumn{3}{|l|}{ Coagulation index ${ }^{3}(48 \mathrm{hr})$} \\
\hline 0 PHA & $0.78 \pm 0.02^{4}$ & $0.90 \pm 0.01$ \\
\hline+ PHA & $0.59 \pm 0.03$ & $0.85 \pm 0.03$ \\
\hline \multicolumn{3}{|l|}{$\begin{array}{l}\text { [3H]Thymidine (cpm } \times \\
\left.10^{3}\right)^{5}\end{array}$} \\
\hline Unstimulated & $1.5 \pm 0.5$ & $1.2 \pm 0.6$ \\
\hline Stimulated & $42.3 \pm 9.0$ & $67.6 \pm 12.1$ \\
\hline \multicolumn{3}{|l|}{$\begin{array}{l}\text { Lymphocyte markers (\% } \\
\text { mononuclear cells) }\end{array}$} \\
\hline E rosette & $61.0 \pm 1.8$ & $66.0 \pm 2.6$ \\
\hline EA rosette & $25.0 \pm 1.6$ & $17.2 \pm 3.4$ \\
\hline $\begin{array}{l}\text { Surface immunoglobulin } \\
\text { bearing }\end{array}$ & $19.8 \pm 1.6$ & $11.0 \pm 1.0$ \\
\hline \multicolumn{3}{|l|}{ Differential $(\%)^{7}$} \\
\hline Neutrophil & $1.6 \pm 0.8$ & $0.5 \pm 0.3$ \\
\hline Lymphocyte & $84.7 \pm 2.9$ & $96.6 \pm 0.8$ \\
\hline Monocyte & $11.5 \pm 1.7$ & $1.3 \pm 0.6$ \\
\hline
\end{tabular}

${ }^{1}$ Mononuclear leukocytes from Ficoll-Hypaque gradients. $(n=15)$.

${ }^{2}$ Adherent mononuclear leukocytes were removed from mixed mononuclear cell populations by polystyrene bead columns (see "Materials and Methods") $(n=12)$.

${ }^{3}$ Significant procoagulant activity is present in the PHA-stimulated mixed mononuclear cell cultures $(P<0.005)$, whereas insignificant activity is present in the adherent cell-depleted cultures.

${ }^{4}$ Mean \pm S.E.

${ }^{5}$ Difference in $\left[{ }^{3} \mathrm{H}\right]$ thymidine incorporation after adherent cell depletion not significant.

${ }^{6}$ Significantly fewer antibody-coated sheep erythrocyte rosetting and immunoglobulin-bearing mononuclear leukocytes are present in the adherent cell depleted cultures than in the mixed cell populations $(P<$ 0.025 ).

${ }^{7}$ Giemsa-stained cytocentrifuge preparations. Significantly fewer monocytes are present in the adherent depleted cultures $(P<0.025)$.

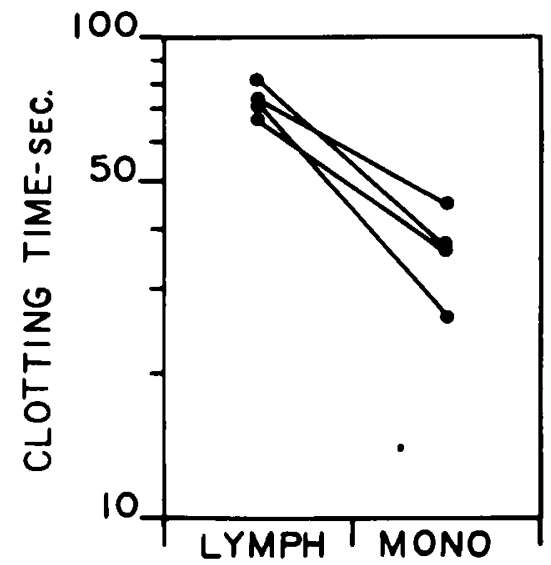

Fig. 5. Enhanced procoagulant activity in monocyte-enriched cell populations. Adherent and nonadherent populations were resuspended at a concentration of $1 \times 10^{6} / \mathrm{ml}$ and incubated for $18 \mathrm{hr}$ before assay. The adherent fraction consisted of $>\mathbf{9 0 \%}$ monocytes (peroxidase-containing mononuclear cells) and the nonadherent $>95 \%$ lymphocytes. The recalcification time of the monocyte enriched population was substantially shorter than the lymphocyte-enriched population.

were partially enriched for monocytes by adherence to glass for 2 hr. The resulting population contained $49.0 \pm 4.1 \%$ monocytes. The cells were resuspended at a concentration of $5 \times 10^{6}$ monocytes per $\mathrm{ml}$, disrupted by sonication, and assayed. The mean recalcification time using normal plasma was $84.6 \pm 6.1 \mathrm{sec}$, 
whereas the recalcification time with factor VIII-deficient plasma was $94.1 \pm 9.4 \mathrm{sec}$. In contrast, the recalcification time with factor VII-deficient plasma was $140.3 \pm 4.2 \mathrm{sec}$. This suggests that the procoagulant activity is acting primarily via the extrinsic limb of coagulation.

\section{DISCUSSION}

It is known that coagulation plays a role in the clinical expression of immunologic disease. This study was designed to examine the association of fibrin formation with immunologically mediated inflammation. We originally postulated that fibrin formation was the result of T-lymphocyte activation and therefore used in vitro cultures of mitogen-stimulated mononuclear leukocytes as a model system. The unexpected observation was that the increase in procoagulant activity was due to activation of a population of adherent mononuclear cells and was not due directly to T-lymphocytes.

We confirmed the initial observation of Rickles et al. (15) that PHA, primarily a T-lymphocyte mitogen (9), stimulates procoagulant activity. Other mitogens, including Con A, a T-lymphocyte mitogen (9), and PWM, a T- and B-lymphocyte mitogen (9), also stimulated procoagulant activity. The magnitude of the procoagulant activity generated in response to varying doses of PHA paralleled the incorporation of tritiated thymidine into replicating DNA. However, mitomycin $C$ in doses sufficient to block DNA synthesis (1) had only a minimal inhibitory effect on the generation of procoagulant activity. Furthermore, we found that the major procoagulant activity was associated with the cells and not the supernatant, suggesting that it is not due to a lymphokine or other secreted product of mononuclear cells.

The dissociation of $\mathrm{T}$-lymphocyte activation from procoagulant activity was confirmed by the demonstration that the development of procoagulant activity required the presence of the adherent mononuclear cell population. Depletion of adherent mononuclear cells (monocytes and some B-lymphocytes) by incubating the cells in polystyrene bead columns resulted in a significant reduction in the ability of the cultures to generate procoagulant activity. Tritiated thymidine incorporation, however, was unaffected by adherent cell depletion. We also demonstrated that monocyte-enriched populations had significantly greater activity than lymphocyteenriched populations. In a separate study (14), we showed that neutrophils contain very little procoagulant activity. Rivers et al. (19) reported the similar observation that endotoxin-stimulated human monocytes are responsible for the procoagulant activity in the peripheral blood leukocytes. The role of T-lymphocyte and monocyte interactions in the development of procoagulant activity is currently under study.

A recent report by Rickles et al. (16) suggested that the procoagulant activity generated by mitogen stimulation of leukocytes may be due to endotoxin contamination of the mitogens or other reagents in the incubation mixture. Their observation could explain our demonstration of activity even when blastogenesis was inhibited by mitomycin. This possibility cannot be definitively evaluated for this study because the specific lots of reagents are not longer available. However, endotoxin is not the only stimulator of procoagulant activity. Rotherberger et al. (20) recently demonstrated that purified IgG and antigen-antibody complexes were capable of stimulating procoagulant activity under conditions in which endotoxin contamination of the stimulating material was minimized. The endotoxin-stimulated procoagulant activity could be differentiated from the activity due to the immunoglobulins on the basis of different sensitivities of immunoglobulin and endotoxin to heat and to polymyxin-B. More studies are needed to evaluate the precise role of endotoxin and other stimulators in the generation of procoagulant activity.

The nature of the procoagulant factor(s) has not been clearly defined. The assay used in this study is responsive to thromboplastic activity, cephalin-like activity, and anticoagulant activity. Our studies and the work of other authors have indicated that the procoagulant factor of endotoxin or PHA-stimulated leukocytes act through the extrinsic pathway of the coagulation cascade and suggests that it is due to tissue thromboplastin on the surface of the cell $(4,11,14,15,19)$. The major role of tissue factor is to combine with factor VII to catalyze the conversion of factor $\mathrm{X}$ to its active form (10). Garg and Niemetz (4) found that the procoagulant activity of rabbit leukocytes could be inhibited by using guinea pig antiserum to tissue factor. Goualt-Heilmann (5) showed partial immunologic identity between human leukocyte derived procoagulant factor and purified tissue factor from known sources.

The procoagulant activity of tissue factor was further investigated by Pitlick (13) who showed that addition of Con A to purified tissue factor apoprotein markedly reduced its procoagulant activity by binding to a carbohydrate residue of the molecule and making it unable to combine with factor VII. In contrast, we showed that addition of Con $A$ to the cell culture resulted in a significant increase in procoagulant activity. We postulate that the increase in activity is the result of de novo protein synthesis (9) in the mitogen-stimulated cells. This could result in an amount of newly synthesized tissue factor which exceeds the binding capacity of Con $A$ in the culture media. However, further studies will be needed to confirm this possibility.

The in vivo significance of mononuclear leukocyte-associated procoagulant activity is a matter of speculation. Inasmuch as activation of the clotting mechanism by circulating leukocytes would be undesirable, the procoagulant factor is probably present in either low concentration or in inactive form. The adherent mononuclear cells (monocytes) are capable of entering the tissue in response to inflammatory stimuli. Neutral proteases and other soluble products are secreted by tissue cells in response to phagocytic (6) or lymphocyte-derived (12) stimuli. Similar stimuli may cause procoagulant factor production and stimulate the deposition of fibrin in the inflammatory site. The leukocyte-derived procoagulant factor, therefore, may serve as a means of modulating the spread of the inflammatory process by stimulating the production of fibrin barriers.

\section{REFERENCES AND NOTES}

1. Bach, F., and Voynow, N.: One-way stimulation in mixed leukocyte culture. Science (Wash. D. C.), 153: 545 (1966).

2. Cohen. S., Benacerraf, B., McCluskey, R., and Ovary, Z.: Effect of anticoagulants on delayed hypersensitivity reactions. J. Immunol., 98: 351 (1967).

3. Colvin, R., Johnson. R., Mihm. M., and Dvorak. H.: Role of the clotting system in cell-mediated hypersensitivity. I. Fibrin deposition in delayed skin reactions in man. J. Exp. Med., 138: 686 (1973).

4. Garg, S., and Niemetz, J.: Tissue factor activity of normal and leukemic cells Blood, 42: 729 (1973).

5. Goault-Heilmann, M., Chardon, E., Sultan, C., and Josso, F.: The procoagulant factor of leukemic promyelocytes: demonstration of immunologic cross reactivity with human brain tissue factor. Br. J. Haematol., 30: 151 (1975).

6. Gordon. S.. Unkeless, J., and Cohn, Z.: Induction of macrophage plasminogen activator by endotoxin stimulation and phagocytosis. J. Exp. Med., 140: 995 (1974).

7. Kociba, G., Loeb, W., and Wall, R.: Development of procoagulant (tissue thromboplastin) activity in cultured leukocytes. J. Lab. Clin. Med., 79: 778 (1972).

8. Lerner, R., Goldstein, R., and Cummings, G.: Stimulation of human leukocyte thromboplastin activity by endotoxin. Proc. Soc. Exp. Biol. Med., 138: 145 (1971).

9. Ling, N., and Kay, J.: Lymphocyte Stimulation. pp. 237-252 (American Elsevier, New York, 1975).

10. Nemerson, Y., and Esnouf, M.: Activation of a proteolytic system by a membrane lipoprotein: mechanism of action of tissue factor. Proc. Natl. Acad. Sci. U. S. A., 70: 310 (1973)

11. Niemetz, J.: Coagulant activity of leukocytes. Tissue factor activity. J. Clin. Invest.. 51: 307 (1972).

12. Pantalone, R., and Page, R.: Lymphokine induced production and release of lysosomal enzymes by macrophages. Proc. Natl. Acad. Sci. U. S. A., 72: 2091 (1975).

13. Pitlick, F. A.: Conconavalin-A inhibits tissue factor coagulant activity. J. Clin Invest., 55: 175 (1975).

14. Rich, K., and Lehrer, R.: Monocytes: the major source of leukocyte procoagulant activity. Pediatr. Res., 10: 380 (1977).

15. Rickles, F., Hardin, J., Pitlick. F.. Hoyer. L., and Conrad, M.: Tissue factor activity in lymphocyte cultures from normal individuals and patients with hemophilia A. J. Clin. Invest., 52: 1427 (1973).

16. Rickles, F. R., Levin, J., Hardin, J. A., Barr, C. F., and Conrad, M. E. et al.: Tissue factor generation by human mononuclear cells: Effects of endotoxin and dissociation of tissue factor generation from mitogenic response. J. Lab. Clin. Med., 89: 792 (1977). 
17. Rinehart, J. J., Gormus, B. J., Lange, P., and Kaplan, M. E.: A new method for isolation of human monocytes. J. Immunol. Methods, 23: 207 (1978).

18. Rivers, R., and Hathaway, W.: Studies on tissue factor activity and production by leukocytes of human umbilical cord and adult origin. Pediatr. Res., 9: 167 (1975).

19. Rivers, R., Hathaway, W., and Weston, W.: The endotoxin-induced coagulant activity of human monocytes. Br. J. Haematol., 30:311 (1975).

20. Rothberger, H.. Zimmerman, T., Spiegelberg, H., and Vaughn, J.: Leukocyte procoagulant activity. J. Clin. Invest., 59: 549 (1977).

21. Seeger, R., Rayner, S., and Owen, J.: An analysis of variables affecting the measurement of tumor immunity in vitro with ${ }^{125}$ I-iododeoxyuridine-labelled target cells. Int. J. Cancer, 13: 1427 (1974).

22. Wood, R., and Bick, M.: The effect of heparin on the ocular tuberculin reaction. Arch. Ophthalmol., 61: 709 (1959).

23. Zacharski, L., Hoyer, L., and McIntyre, R.: Immunologic identification of tissue factor (thromboplastin) synthesized by cultured fibroblasts. Blood, 41: 671
(1973).

24. Zighelboim, J., Gale, R., Chiu, A., Bonavida, B., Ossorio, R. C., and Fahey, J. L.: Antibody dependent cellular cytotoxicity: cytotoxicity mediated by nonT-lymphocytes. Clin. Immunol. Immunopathol., 3: 193 (1974).

25. The present address of D. R. A. Robins is: Cancer Research Campaign Laboratories, University Park, Nottingham, England.

26. Requests for reprints should be addressed to: Kenneth C. Rich, M.D., Division of Immunology, The Children's Memorial Hospital, 2300 Children's Plaza, Chicago. IL 60614 (USA)

27. This research was supported in part by a United States Public Health Service (NICHD) Special Postdoctoral Fellowship and Research Grants HD-9800 of the National Institute of Health and 6-19 of the National Foundation-March of Dimes. Dr. Rich is a recipient of the Basil O'Connor Research Grant of the National Foundation-March of Dimes. 5-161.

28. Received for publication August 14, 1979.

29. Accepted for publication June 13, 1980. 